\title{
Characterization of two Moroccan watermelon seeds oil varieties by three different extraction methods ${ }^{\text {h }}$
}

\author{
Ihssane Ouassor, Younes Aqil, Walid Belmaghraoui and Souad El Hajjaji* \\ Laboratory of Spectroscopy, Molecular Modeling, Materials, Nanomaterials, Water and Environment, CERNE2D, Faculty of Sciences, \\ Mohammed V University in Rabat, Av Ibn Battouta, BP1014, Agdal, Morocco
}

Received 5 December 2019 - Accepted 4 March 2020

\begin{abstract}
The purpose of this study is to assess and evaluate the physicochemical properties of the seed oils of two Moroccan varieties of watermelon "Citrullus lanatus" extracted by three different techniques, a mechanical process using cold press, and two chemical processes using a Soxhlet apparatus and a sonotrode ultrasound assisted extraction (UAE) using n-hexane. The total phenolic compounds (TPC) and antioxidant properties against the DPPH radicals (2,2-diphenyl-1-picrylhydrazyl) were also studied. The seed oils of both varieties of watermelon exhibited high concentrations of unsaturated fatty acids with the predominance of linoleic and oleic fatty acids. The primary sterol was $\beta$-sitosterol, and high levels of total tocopherols were observed. Y-tocopherol was the predominant tocopherol in all tested oils. The Citrullus lanatus var. lanatus variety seeds oil exhibited the highest TPC value $(89.5 \pm 0.06 \mathrm{mg} \mathrm{EGA} / 100 \mathrm{~g}$; EGA: gallic acid equivalent), with $82.4 \pm 0.03 \%$ DPPH free radical inhibition efficiency. Nevertheless, all tested seeds oils showed a significant amount of total phenolic compounds and a good inhibition against DPPH radicals ranging from $51.1 \pm 0.1 \%$ to $84.8 \pm 0.04 \%$. In addition, the influence of the ultrasonic extraction parameters was studied using two different solvents (n-hexane and the methanol-chloroform mixture), with different particle sizes $(500-300 \mu \mathrm{m})$, duration (10 and 20 minutes), cycle (1-0.5), amplitude ( $80-100 \%)$ and solvent/seed ratios (1:5 and 1:10), and the seed roasting parameter was also studied. The oil yield was mainly affected by the extraction solvent, then the solvent/seed ratio and the duration, respectively.
\end{abstract}

Keywords: Citrullus lanatus / sonotrode / physicochemical / antioxidant / Taguchi

Résumé - Caractérisation de deux variétés d'huile de graines de pastèque marocaine par trois méthodes d'extraction différentes. L'objectif de cette étude est d'évaluer les propriétés physico-chimiques d'huiles de graines de deux variétés marocaines de pastèques Citrullus lanatus extraites par trois techniques différentes, un procédé mécanique utilisant la presse à froid, et deux procédés chimiques utilisant un appareil de Soxhlet et une sonotrode d'extraction assistée par ultrasons (EAU) utilisant le n-hexane. Les composés phénoliques totaux (TPC) et les propriétés anti-oxydantes contre les radicaux DPPH (2,2-diphényl-1picrylhydrazyl) ont également été étudiés. Les huiles de graines des deux variétés de pastèques présentaient des concentrations élevées d'acides gras insaturés, avec une prédominance d'acides gras linoléiques et oléiques. Le stérol le plus abondant était le $\beta$-sitostérol, et des niveaux élevés de tocophérols totaux ont été observés. Y-tocophérol était le tocophérol prédominant dans toutes les huiles testées. L'huile de graines de la variété Citrullus lanatus var. lanatus s'est avérée la plus riche en PTC $(89,5 \pm 0,06 \mathrm{mg}$ EGA/100 g; EGA : gallic acid equivalent), avec une efficacité d'inhibition des radicaux libres de $82,4 \pm 0,03 \%$ DPPH. Toutes les huiles de graines testées contenaient une quantité significative de composés phénoliques totaux et une bonne capacité d'inhibition contre les radicaux DPPH (de $51,1 \pm 0,1 \%$ à $84,8 \pm 0,04 \%$ ). En outre, l'influence des paramètres d'extraction par ultrasons a été étudiée en utilisant deux solvants différents (le nhexane et le mélange méthanol-chloroforme), avec des tailles de particules de graines $(500-300 \mu \mathrm{m})$, des durées ( 10 et 20 minutes), des cycles (1-0,5), des amplitudes (80-100\%) et des rapports solvant/graines (1:5 et 1:10) différents, et le paramètre de torréfaction des graines a également été étudié. Le rendement

\footnotetext{
it Contribution to the Topical Issue "Minor oils from atypical plant

sources / Huiles mineures de sources végétales atypiques".

*Correspondence: souad.elhajjaji@um5.ac.ma
} 
d'extraction de l'huile a été principalement affecté par le solvant d'extraction, puis par le rapport solvant sur graines et la durée, respectivement.

Mots clés : Citrullus lanatus / sonotrode / physicochimique / antioxydant / Taguchi

\section{Introduction}

Recently, the demand of vegetable oils is increasing dramatically for its non-edible uses, for example in pharmaceutical and cosmetics care products. The demand for these oils is mainly due to its richness in lipophilic compounds, and the high concentrations of polyunsaturated fatty acids, sterols and tocopherols. However, only 12 known plant species are exploited commercially to produce vegetable oils, a low amount compared to the strong increasing demand of either food or cosmetic industries, which incites the search for new sources of vegetable oils associated with nutritional characteristics, health-promoting and cosmetic interest features (Mabaleha et al., 2007).

Simultaneously, a large volumes of waste or by-products are generated by the fruit industry during the production, preparation or processing of the fruits, in part in the form of seeds generating problems of treatment and elimination, resulting in pollution, but also a loss of a precious source of nutrients that can be beneficial for other industries such as the production of oils and functional ingredients (Karmel et al., 1982; El-Adawy and Taha, 2001).

Watermelon seeds have the potential to be used in other industries so that they can become a raw material because they remain intact after removal of the pulp and skin during fruit consumption or in the production of juices, marmalades, jams, sweets, etc. (Rai et al., 2015), and are only considered waste by the food industries.

In the African and Asian cultures, watermelon was used as a medicinal plant (Simpson and Morris, 2014), the seeds are exploited in urinary infectious, gastrointestinal, leucorrhea, gonorrhea and prostatic diseases (Olamide and Olayemi, 2011; Lucky et al., 2012; Varghese et al., 2013). Watermelon seed oil has been used since Pharaonic times as a skincare and as acne treatment in India (Vermaak et al., 2011). The oil has also been used for hydration and protection against sunburn (Van Damme et al., 1992).

In Morocco, there is a large number of varieties of watermelon including those with seeds that are the most available (Sangria, Fiesta, Calsweet, Royal) and the triploid group, without seeds, less present in Morocco (Nova, Laurel, Fire Cracker, etc.) (AuthorAID Resource Library, 2019). These varieties are established mainly for consumption or production while there is a bitter variety of watermelon "Citroides" non-consumable planted especially for its seeds used by Moroccans as food or in the preparation of traditional delights.

In this study, we have compared two Moroccan varieties of watermelon seed oils extracted using three different techniques, by the determination of the physicochemical properties, fatty acids, sterols and tocopherols compositions. In this present work, we also compares the antioxidant activities and the total polyphenol content of the different oils extracted in addition to the effects of solvent, granulometry, duration, cycle, amplitude, roasting and solvent/kernel ratio on the Ultrasound assisted extraction of watermelon seed oil, which was done by the Taguchi method that uses special orthogonal arrays to study all the design parameters independently of one another, using a minimum number of experiments.

\section{Material and methods}

\subsection{Raw material}

Watermelons of both varieties "Citrullus lanatus var. lanatus" and "Citrullus lanatus var. citroides" (Fig. 1) were sourced locally in Rabat city region, Morocco. After being washed in a thorough manner with water, the fruits were opened to pick up the seeds inside and then washed with distilled water and left to dry at room temperature in shade. The dried seeds were stored in hermetic bags at $4{ }^{\circ} \mathrm{C}$ till further use. All seeds were brought to a room temperature prior to their use.

\subsection{Oil extraction methods}

\subsubsection{Cold press extraction}

The cold press extraction was performed using a Kern Kraft prince $\mathrm{F}$ universal, with a $2.2 \mathrm{~kW}$ engine mechanical screw press. The seeds were blended beforehand in a domestic kitchen mixer grinder without any pretreatment.

\subsubsection{Soxhlet extraction}

Thirty grams of seeds flour of each variety were placed in a paper thimble and fed into a $250 \mathrm{~mL}$ capacity Soxhlet extractor. The extractor was fitted with a $500 \mathrm{~mL}$ round bottomed flask containing $300 \mathrm{~mL}$ of solvent. The oil extraction was carried out with n-hexane on a flask heater at $80^{\circ} \mathrm{C}$ for $2 \mathrm{~h}$.

\subsubsection{Sonotrode ultrasound assisted extraction (SUAE)}

The extraction was conducted using US sonotrode (UP $100 \mathrm{H}$, Hielscher, Germany) equipped with a $7-\mathrm{mm}$ diameter probe $(24 \mathrm{KHz})$ (Hielscher, Germany). This extraction was conducted with seed granulometry of $500 \mu \mathrm{m}$, a ratio of 1:5, an amplitude of 80 , a 0.5 cycle without seed roasting and with hexane for 10 minutes. The solution was kept to stand, filtered through a whatman filter paper and then the hexane separated from the oil.

\subsubsection{Taguchi "Sonotrode ultrasound assisted extraction (SUAE)" optimization}

The effect of solvent, granulometry, duration, cycle, amplitude, roasting and solvent/kernel ratio on ultrasound assisted extraction of watermelon oil yield was investigated. $5 \mathrm{~g}$ of powdered watermelons seeds of only the "Citrullus lanatus var. citroides" were ultrasonically extracted (sonotrode 


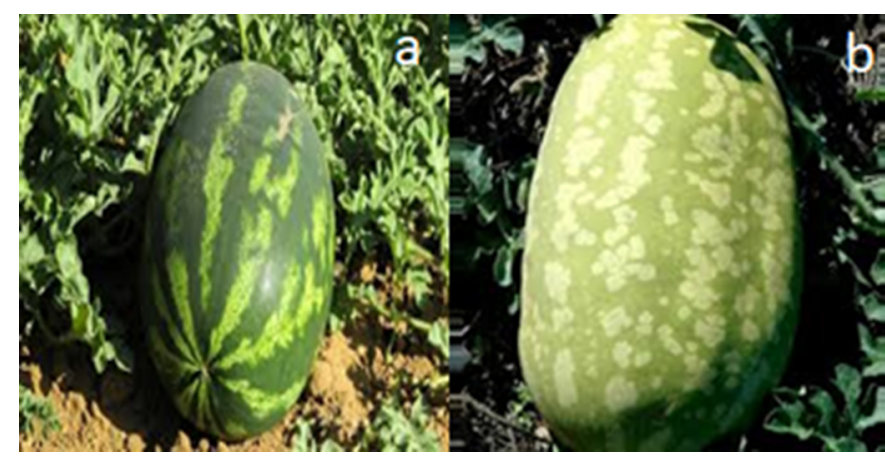

Fig. 1. a: Citrullus Lanatus var. Lanatus; b: Citrullus Lanatus var. Citroides.

ultrasound assisted extraction (SUAE)) under different combination of considered parameters (duration: 10 and 20 minutes, particle sizes: 500 and $300 \mu \mathrm{m}$, cycle: 0 and 1 , amplitude: 80 and $100 \%$, solvent/kernel ration: $1: 5$ and 1:10, seeds roasting and nature of solvent). The seed roasting was performed an FN400 stove at $100^{\circ} \mathrm{C}$ for 20 minutes. The extraction was achieved with an US sonotrode (UP $100 \mathrm{H}$, Hielscher, Germany) equipped with a 7-mm diameter probe $(24 \mathrm{KHz})$ (Hielscher, Germany). The solution was kept to stand, filtered through a whatman filter paper. Then, the solvent was removed and the oil was weighed to calculate the yield extraction.

The Taguchi method with an L8 array scheme was adapted and employed to reduce the number of experiments. Two levels are defined for each parameter which required 8 experiments. After conducting the experiments, the results were converted into signal-to-noise $(\mathrm{S} / \mathrm{N})$ ratio data. In the Taguchi method, the "S/N" data is subjected to analysis of variance (Ross, 1988).

The chosen conditions of sonotrode ultrasound-assisted extraction (SUAE) are according to previously reported studies (Samaram et al., 2015; Senrayan and Venkatachalam, 2018).

Oils were separated from the solvent using a rotary evaporator (Rotavapor R-100, BUCHI) and kept in sealed brown bottles under refrigeration $\left(4^{\circ} \mathrm{C}\right)$ for further analysis.

\subsubsection{Determination of extraction yield}

The extraction yield was obtained by dividing the amount of the extracted oil to the initial amount of seeds flour used in the extraction and multiplying by 100 . A $0.0001 \mathrm{~g}$ analytical balance was used for accurate balancing (Bimakr et al., 2012).

$$
\operatorname{Yield}(\%)=\frac{w_{\mathrm{f}}}{w_{\mathrm{i}}} \times 100
$$

Where: $\mathrm{W}_{\mathrm{f}}$ is the weight of the extracted oil and $\mathrm{W}_{\mathrm{i}}$ is the weight of the initial seeds flour.

\subsubsection{Determination of physicochemical characteristics}

The peroxide value was determined according to ISO 3960 standard method, the free fatty acid (FFA) content was determined using the ISO 660 standard protocol and the acid value was determined mathematically by multiplying the FFA value by a 1.99 factor.

The saponification value was determined according to ISO 3657 standard method and the iodine value was calculated from the fatty acids composition using the ISO 3961 method.

\subsubsection{Carotenoids analysis}

In this assay, $0.8 \mathrm{~g}$ of oil was dissolved in $25 \mathrm{~mL}$ of $\mathrm{n}$ hexane and the absorbance was measured at $446 \mathrm{~nm}$. The total carotenoids content was expressed as $\mathrm{mg} / \mathrm{kg}$ (PORIM Test Methods, 1995).

\subsubsection{Extraction of phenolics from the oil}

The extraction of phenolic compounds from "Citrullus lanatus var. lanatus \& var. citroides" seeds for the different method of oils extractions was carried out using the method of Owen et al. (2000), with some modifications. Briefly, $2 \mathrm{~g}$ of each oil sample oil was extracted three times with $10 \mathrm{~mL}$ of a methanol: water solution (8:2), after vortexing for 2 minutes and centrifugation at $3000 \mathrm{rpm}$ for 10 minutes at each extraction. The methanolic extracts were combined then washed three times with $10 \mathrm{~mL}$ n-hexane to remove lipid components. The methanolic fraction was separated and evaporated using a rotary evaporator at reduced pressure, and the dry residue is used for the colorimetric assay and antioxidant activity (Owen et al., 2000).

\subsubsection{Total phenolic compounds determination (TPC)}

The total phenolic content was performed using the FolinCiocalteu colorimetric method (Lister and Wilsan, 2001). $500 \mu \mathrm{L}$ of the sample solution was mixed with $2500 \mu \mathrm{L}$ of Folin-Ciocalteu reagent in distilled water (1:10), and $4000 \mu \mathrm{L}$ of $\mathrm{Na}_{2} \mathrm{CO}_{3}(7.5 \%, \mathrm{w} / \mathrm{v})$ was added. After 30 minutes of incubation in a $45^{\circ} \mathrm{C}$ water bath, the absorbance is measured at $765 \mathrm{~nm}$ and compared to a blank using a UV-Vis spectrophotometer.

The concentration of total polyphenols is calculated from the regression equation of the calibration curve established with gallic acid over a concentration range $0-300 \mu \mathrm{g} / \mathrm{mL}$. Phenolic content values were expressed as Gallic acid equivalent (mg GAE/g oil extract).

\subsubsection{Antioxidant activity by the free radical DPPH assay}

The anti-radical activity of the methanolic oil extracts was evaluated by the DPPH radical scavenging measure, according to the protocol described by Huang et al. (2011).

$500 \mu \mathrm{L}$ of a $0.2 \mathrm{mM}$ DPPH solution was mixed with $2500 \mu \mathrm{L}$ of the sample solution. The mixture is left in the dark for $30 \mathrm{~min}$ at $25^{\circ} \mathrm{C}$ and the discoloration compared to the negative control containing only the DPPH solution is measured at $517 \mathrm{~nm}$. The radical-scavenging activity (RSA) was expressed as the percentage of fading of DPPH according to the equation:

$$
\% \mathrm{RSA}=\frac{A-A_{S}}{A} \times 100
$$


Table 1. The results of L8 test performed on the "Citrullus lanatus var. citroides".

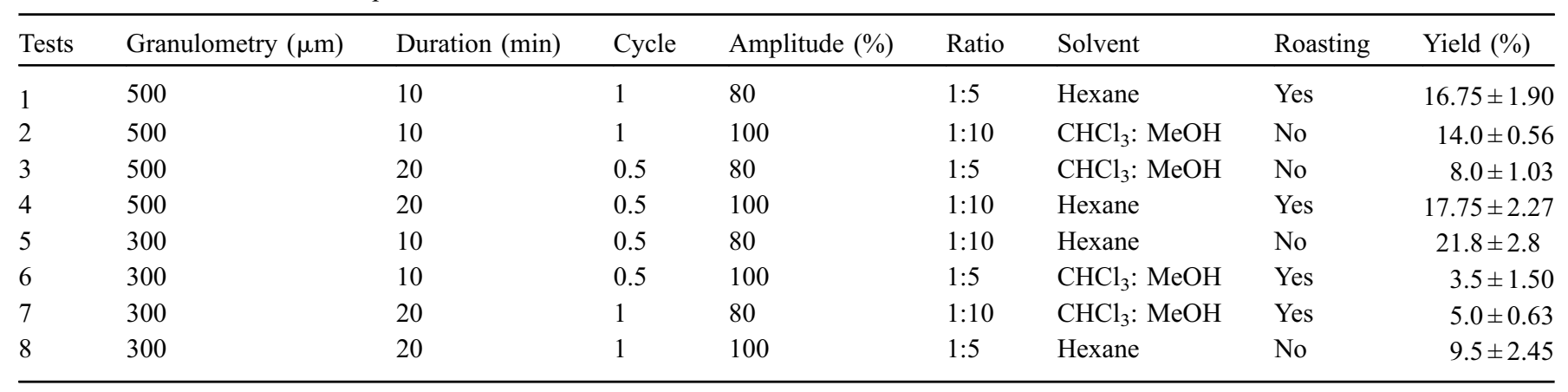

Data shown as means with $\pm \mathrm{SD}$ of three replicates.

Where: $A$ is the recorded absorbance of the blank sample, $A_{S}$ is the absorbance value of the sample solution.

\subsubsection{Gas-chromatography for fatty acids composition}

The fatty acid methyl esters (FAME) composition was determined following EEC/2568/91 protocol (EEC/2568, 2003), by capillary gas chromatography-CGC, using a Varian CP-3800 (Varian Inc.) chromatograph equipped with an FID. A split injector was used, and the injected volume was $1 \mathrm{~mL}$. The column used was a CP- Wax 52CB column $(30 \mathrm{~m} \times 0.25$ mm i.d.; Varian Inc., Middelburg, The Netherlands). The conditions for the chromatographic operations were as follows: The carrier gas was helium and the total gas flow rate was $1 \mathrm{~mL} / \mathrm{min}$. The initial and final column temperature was 170 and $230{ }^{\circ} \mathrm{C}$, respectively, and the temperature was increased by steps of $4{ }^{\circ} \mathrm{C} / \mathrm{min}$. The injector and detector temperature were $230{ }^{\circ} \mathrm{C}$. Data were processed using a Varian Star Workstation v 6.30 (Varian Inc., Walnut Creek, CA, USA). Results were expressed as the relative percentage of each individual FA presents in the sample.

\subsubsection{Tocopherols contents determination}

The tocopherol contents of the samples were determined according to the ISO 9936 standard method using an HPLC equipped with a fluorometric detector (excitation wavelength $290 \mathrm{~nm}-$ emission wavelength $330 \mathrm{~nm}$ ) on a silica column $(25 \mathrm{~cm} \times 4 \mathrm{~mm})$. The elution is carried out with a mixture of (isooctane: isopropanol) (99:1) with a flow rate of $1.2 \mathrm{~mL} / \mathrm{min}$ during the analysis time $(20 \mathrm{~min})$. Quantification was carried out by external standard curves of four tocopherols and daily reference of quantitative and qualitative tocopherol standards.

\subsubsection{Phytosterols quantification}

The phytosterols were quantified according to the ISO 6799 standard method using capillary gas chromatography CGC on an apolar column (Chroma pack) $(30 \mathrm{~m} \times 0.32 \mathrm{~mm}$, DI: $0.25 \mu \mathrm{m}$, phase: CPSIL8CB). The VARIAN CP-3800 chromatograph is equipped with a divider injector type 1079 (T: $300^{\circ} \mathrm{C}$ ) and an FID (T: $300^{\circ} \mathrm{C}$ ). The carrier gas is helium (flow: $1.5 \mathrm{~mL} / \mathrm{min}$ ). The analysis is carried out in isothermal programming at $270{ }^{\circ} \mathrm{C}$. for $30 \mathrm{~min}$ ) on a capillary column $($ VF-5ht $(30 \times 0.25 \mathrm{~mm}$ DI DF $=0.1)$.

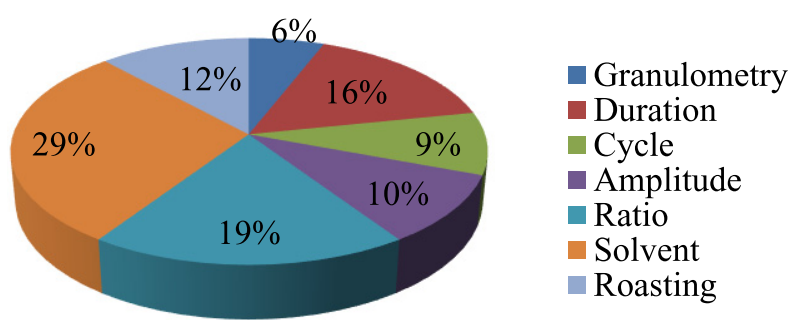

Fig. 2. Significant parameters influencing on SUAE seed oil extraction performed on the "Citrullus lanatus var. citroides".

\section{Results and discussion}

The Sonotrode ultrasound assisted extraction (SUAE) results performed under the Taguchi method with an L8 array scheme design conditions are shown in Table 1 . The results show that by using the n-hexane as an extraction solvent, the oil extraction yield was improved.

The significant parameters on oil extraction as a percentage of influences indicate that the solvent had a greatest influence on the SUAE oil extraction followed by the solvent/kernel ratio (Fig. 2).

The oil yields and the physicochemical properties of the oils extracted from the two varieties of Moroccan watermelon seeds obtained from different extractions in the same conditions are given in Table 1 . The cold pressing extraction method produced yields of $(21.4 \pm 1.50 \%)$ and $(10.6 \pm 2.45 \%)$ for "Citrullus lanatus var. citroides" and "Citrullus lanatus var. lanatus" respectively. These yields remain lower than the solvent extraction methods where the oil yields were the highest in Soxhlet extraction $(36.3 \pm 1.90 \%$ and $33.0 \pm 1.80 \%)$ followed by SUAE extraction $(21.8 \pm 2.3 \%$ and $19.3 \pm 3.10 \%)$. This was expected since the extraction yields by the mechanical method are often lower than those by solvent extractions (Carr, 1989).

The physicochemical properties of the oils extracted from the two varieties of Moroccan watermelon seeds obtained from different extractions are given in Table 2.

The iodine value reflects the degree of unsaturation of the fatty acids constituting the oil (Khattab and Zeitoun, 2013). The found results of iodine value ranged from 112.6 to $116.5 \mathrm{~g}$ (I2/100 g of oil), a comparable value with those of Cheikhyoussef et al. (2017), ranging from 110.28 to 
Table 2. Physicochemical properties of watermelons seeds oils.

\begin{tabular}{|c|c|c|c|c|c|c|}
\hline Determination & \multicolumn{3}{|c|}{ Citrullus lanatus var. lanatus } & \multicolumn{3}{|c|}{ Citrullus lanatus var. citroides } \\
\hline Saponification value (mg KOH/g oil) & $167.2 \pm 1.20$ & $161.2 \pm 1.41$ & $166.2 \pm 1.85$ & $169.2 \pm 0.90$ & $164.1 \pm 1.15$ & $162.3 \pm 1.90$ \\
\hline Calculated iodine value (g I/100 g oil) & 116.34 & 116.5 & 116.3 & 113.17 & 112.6 & 112.6 \\
\hline Acid value (mg KOH/g oil) & $2.8 \pm 0.06$ & $1.40 \pm 0.03$ & $2.8 \pm 0.069$ & $21.2 \pm 0.08$ & $20.04 \pm 0.01$ & $20.8 \pm 0.87$ \\
\hline Peroxide value ( $\mathrm{m} \mathrm{eq}_{2} / \mathrm{kg}$ oil) & $3.8 \pm 0.20$ & $6.0 \pm 0.08$ & $4.0 \pm 0.67$ & $4.0 \pm 0.22$ & $2.0 \pm 0.20$ & $10.0 \pm 0.18$ \\
\hline
\end{tabular}

Data shown as means with $\pm \mathrm{SD}$ of three replicates.

$118.61 \mathrm{~g}$ (I2/100 g of oil) for the variety "lanatus". However, higher values were found by Baboli and Kordi (2010), with Iranian variety of watermelon $(156 \mathrm{~g} \mathrm{I} / 100 \mathrm{~g}$ oil) and lower values with the "Tsama C. Lanatus" variety (95 g I2/100 g oil) obtained by Mabaleha et al. (2007), which indicates that our oils have the ability to absorb oxygen when exposed to the atmosphere since the iodine values are higher than 100 and less than 150, suggesting that the "lanatus" and "citroides" varieties can be used for soap formulations.

The saponification value gives an idea of the average molecular weight of the vegetable oil. The saponification values obtained $(161.2 \pm 1.41$ to $167.2 \pm 1.20 \mathrm{mg} \mathrm{KOH} / \mathrm{g}$ oil $)$ were lower than those found by Nolte and von Loesecke (1939), Baboli and Kordi (2010) and De conto et al. (2011), 197,192 and $200 \mathrm{mg}$ of $\mathrm{KOH} / \mathrm{g}$ of oil, respectively for the Cuban Queen variety, Top Gun variety and the Iranian watermelon variety.

The acid values for the "lanatus" seeds oils with the different techniques of extraction $(1.40 \pm 0.03$ and $2.8 \pm 0.06 \mathrm{mg} \mathrm{KOH} / \mathrm{g}$ oil) and peroxide values $(6.0 \pm 0.08$, $4.0 \pm 0.67$ and $3.8 \pm 0.20 \mathrm{~m} \mathrm{eq}_{2} / \mathrm{kg}$ oil) are in agreement with those Baboli and Kordi (2010), $2.4 \pm 0.1 \mathrm{mg} \mathrm{KOH} / \mathrm{g}$ oil for acid value, $3.24 \pm 0.1 \mathrm{~m} \mathrm{eq}_{2} / \mathrm{kg}$ oil for peroxide value and matches perfectly the Codex standards for vegetable oils. While for the "citroides" variety, high values were obtained in the order of $20 \mathrm{mg} \mathrm{KOH} / \mathrm{g}$ of oil for the acid value and $10 \mathrm{meq} \mathrm{O}_{2} / \mathrm{kg}$ of oil for the peroxide value obtained in ultrasonic extraction, indicating that this variety of oil is unstable under the ultrasonic condition of extraction and is susceptible to auto-oxidation (Adebisi and Olagunju, 2011), and conversely for oils of the "lanatus" variety where the low values of acidity and peroxide value suggest its high degree of stability. However the "citroides" variety turned out to have a high acid value, suggesting that it is rich in free fatty acids, which explains the fact that it is not suitable for consumption.

Significant levels of carotenoids; acts as pro-oxidants in vegetable oils (Tab. 2) were detected in the oils. The cold pressed oil sample of "Citrullus lanatus var. citroides" had the highest total carotenoid concentration $(73.95 \pm 0.20 \mathrm{mg} / \mathrm{Kg})$, followed by the soxhlet "Citrullus lanatus var. lanatus" oil sample. "Citrullus lanatus var. citroides" had the lowest carotenoids amount $(18.31 \pm 0.22 \mathrm{mg} / \mathrm{Kg})$ for SUAE sample. This results stays different to those of De conto et al. (2011), with the Top Gun variety, $30.55 \mathrm{mg} / \mathrm{Kg}$ for solvent extracted oil and $39.14 \mathrm{mg} / \mathrm{Kg}$ for expeller extracted oil.
The fatty acid compositions of "Citrullus lanatus var. lanatus" and "Citrullus lanatus var. citroides" by the different techniques of extraction are shown in Table 3. A close resemblance between the two varieties is very apparent, the major fatty acid is linoleic acid, followed by oleic acid and palmitic acid for both varieties, and myristic, linolenic and stearic acids are also present in low amounts. The highest percentage of linoleic acid is given by the oil extracted by soxhlet $67.43 \%$ for the variety "lanatus" and the highest percentage of oleic acid is obtained with the oil of the variety "citroides" with both cold pressed and SUAE extraction techniques 19.08 and $16.65 \%$ respectively. Our results in linoleic acid are in agreement with those of Baboli and Kordi (2010); (68.3\%) with the Iranian variety, and Nolte and von Loesecke (1939); (65.85\%) with the Cuban Queen variety and slightly higher with El-Adawy and Taha (2001); (59.61\%) with the Citrullus vulgaris variety, although in oleic acid (18.07\%). The difference noticed is probably due to the variety used in each study.

Linoleic and oleic acids rich oils are particularly important for the human diet. They help maintain membrane fluidity at the water barrier of the epidermis, and can be further enzymatically oxidized to a variety of derivatives involved in cell signaling.

Interestingly, the studied oils are rich in palmitic and stearic acids, which are at the origin of these two fatty acids, explaining the presence in small amounts, Margaric and Margaroleic acids in these oils.

Mean values of the total phytosterols for "Citrullus lanatus var. lanatus" and "Citrullus lanatus var. citroides" were 332.54 and $379.82 \mathrm{mg} / 100 \mathrm{~g}$ oil respectively for Soxhlet extraction, and 366.15 and $238.92 \mathrm{mg} / 100 \mathrm{~g}$ oil for SUAE extraction and 471.79 and $370.6 \mathrm{mg} / 100 \mathrm{~g}$ oil for cold pressing extraction (Tab. 4). These results are slightly different from one extraction technique to another and from one variety to the other, indicating that the oil properties are extraction technique and variety dependent. These values are higher than those found by De conto et al. (2011), 247.83 and $205.88 \mathrm{mg} / 100 \mathrm{~g}$ of oil by solvent and expeller respectively with the Top Gun Variety.

Table 4 shows the phytosterols compositions of watermelon seed oils extracted by cold pressing, soxhlet and SUAE of both varieties. The phytosterols present in greater quantity were $\beta$-Sitosterol followed by $\Delta$-5-24-Stigmastadienol.

The highest $\beta$-sitosterol value was found in the oil of "Citrullus lanatus var. citroides" with SUAE extraction 
Table 3. Fatty acid compositions $(\%, \mathrm{w} / \mathrm{w})$ of Citrullus lanatus var. lanatus and Citrullus lanatus var. citroides seeds oil.

\begin{tabular}{|c|c|c|c|c|c|c|}
\hline Fatty acids & \multicolumn{3}{|c|}{ Citrullus lanatus var. lanatus } & \multicolumn{3}{|c|}{ Citrullus lanatus var. citroides } \\
\hline C14:0 Myristic acid & $0.04 \pm 0.01$ & $0.04 \pm 0.01$ & $0.04 \pm 0.01$ & $0.05 \pm 0.01$ & $0.05 \pm 0.01$ & $0.05 \pm 0.01$ \\
\hline C16:0 Palmitic acid & $10.29 \pm 0.35$ & $10.28 \pm 0.36$ & $10.29 \pm 0.35$ & $10.07 \pm 0.31$ & $10.43 \pm 0.33$ & $10.29 \pm 0.29$ \\
\hline C16:1 Palmitoleic acid & $0.07 \pm 0.01$ & $0.07 \pm 0.01$ & $0.07 \pm 0.01$ & $0.1 \pm 0.01$ & $0.08 \pm 0.01$ & $0.08 \pm 0.01$ \\
\hline C17:0 Margaric acid & $0.10 \pm 0.01$ & $0.11 \pm 0.01$ & $0.10 \pm 0.01$ & $0.06 \pm 0.01$ & $0.06 \pm 0.01$ & $0.06 \pm 0.01$ \\
\hline C18:1 Oleic acid & $14.76 \pm 0.80$ & $14.75 \pm 0.84$ & $14.76 \pm 0.79$ & $19.08 \pm 1.07$ & $16.63 \pm 0.94$ & $16.65 \pm 0.94$ \\
\hline C18:2 Linoleic acid & $67.06 \pm 0.95$ & $67.43 \pm 0.97$ & $67.06 \pm 0.92$ & $61.76 \pm 0.91$ & $63.76 \pm 0.92$ & $63.74 \pm 0.95$ \\
\hline C18:3 Linolenic acid & $0.3 \pm 0.05$ & $0.16 \pm 0.02$ & $0.3 \pm 0.08$ & $0.46 \pm 0.11$ & $0.07 \pm 0.01$ & $0.06 \pm 0.01$ \\
\hline C20:0 Arachidic acid & $0.29 \pm 0.09$ & $0.27 \pm 0.09$ & $0.29 \pm 0.08$ & $0.32 \pm 0.11$ & $0.31 \pm 0.10$ & $0.32 \pm 0.08$ \\
\hline C20:1 Gadoleic acid & $0.10 \pm 0.01$ & $0.08 \pm 0.01$ & $0.10 \pm 0.01$ & $0.11 \pm 0.01$ & $0.09 \pm 0.01$ & $0.08 \pm 0.01$ \\
\hline
\end{tabular}

Table 4. Phytosterols compositions of the "Citrullus lanatus var. lanatus" and "Citrullus lanatus var. citroides" seed oils obtained from each type of extraction.

\begin{tabular}{|c|c|c|c|c|c|c|}
\hline Sterols & \multicolumn{3}{|c|}{ Citrullus lanatus var. lanatus } & \multicolumn{3}{|c|}{ Citrullus lanatus var. citroides } \\
\hline Cholesterol & $0.13 \pm 0.01$ & $0.13 \pm 0.01$ & $0.15 \pm 0.01$ & $1.99 \pm 0.01$ & $0.1 \pm 0.01$ & $0.14 \pm 0.01$ \\
\hline Campesterol & $0.57 \pm 0.11$ & $0.66 \pm 0.02$ & $0.39 \pm 0.07$ & $2.38 \pm 0.1$ & $0.46 \pm 0.06$ & $0.4 \pm 0.04$ \\
\hline Stigmasterol & $2.43 \pm 0.04$ & $3.23 \pm 0.05$ & $3.08 \pm 0.04$ & $3.66 \pm 0.05$ & $2.16 \pm 0.03$ & $2.13 \pm 0.02$ \\
\hline B-Sitosterol & $55.45 \pm 0.98$ & $49.23 \pm 0.89$ & $53.69 \pm 0.91$ & $60.36 \pm 0.96$ & $57.55 \pm 1.02$ & $62.52 \pm 0.99$ \\
\hline$\Delta$-7-Stigmasterol & $5.32 \pm 0.06$ & $5.92 \pm 0.07$ & $5.46 \pm 0.05$ & $2.06 \pm 0.02$ & $2.38 \pm 0.03$ & $2.09 \pm 0.02$ \\
\hline$\Delta-5$-Avenasterol & $2.32 \pm 0.03$ & $2.49 \pm 0.05$ & $2.49 \pm 0.02$ & $1.62 \pm 0.03$ & $2.03 \pm 0.04$ & $1.85 \pm 0.1$ \\
\hline Others & $1.61 \pm 0.03$ & $3.56 \pm 0.07$ & $1.73 \pm 0.04$ & $2.44 \pm 0.04$ & $3.22 \pm 0.08$ & $1.81 \pm 0.02$ \\
\hline Total phytosterols content $(\mathrm{mg} / 100 \mathrm{~g})$ & $471.79 \pm 2.44$ & $332.54 \pm 1.25$ & $366.15 \pm 1.24$ & $370.6 \pm 1.55$ & $379.82 \pm 2.1$ & $238.92 \pm 1.99$ \\
\hline
\end{tabular}

Table 5. Tocopherols compositions of "Citrullus lanatus var. lanatus" and "Citrullus lanatus var. citroides" seed oils obtained from each type of extraction.

\begin{tabular}{|c|c|c|c|c|c|c|}
\hline Tocopherols (mg/Kg) & \multicolumn{3}{|c|}{ Citrullus lanatus var. lanatus } & \multicolumn{3}{|c|}{ Citrullus lanatus var. citroides } \\
\hline$\alpha$-tocopherol & $34.05 \pm 1.25$ & $16.32 \pm 0.94$ & $15.66 \pm 0.91$ & $15.5 \pm 0.13$ & $12.54 \pm 0.51$ & $8.0 \pm 0.11$ \\
\hline$\gamma$-tocopherol & $1694.16 \pm 4.04$ & $867.21 \pm 3.77$ & $826.36 \pm 3.04$ & $1436.84 \pm 5.37$ & $960.11 \pm 4.01$ & $953.7 \pm 3.94$ \\
\hline$\delta$-tocopherol & - & $9.87 \pm 0.72$ & $14.25 \pm 0.99$ & - & $21.65 \pm 1.38$ & $28.92 \pm 1.42$ \\
\hline Total tocopherols $(\mathrm{mg} / \mathrm{Kg})$ & $2310.3 \pm 6.25$ & $893.4 \pm 5.22$ & $856.27 \pm 6.04$ & $4983.65 \pm 7.28$ & $994.3 \pm 6.19$ & $990.62 \pm 6.35$ \\
\hline
\end{tabular}

corresponding to $62.52 \%$, against $53.69 \%$ for the oil of the "lanatus" variety, and only $49.23 \%$ with solvent extraction. These results do not agree with those of De conto et al. (2011), with the Top Gun Variety where stigmasterol is the predominant phytosterol with about $47 \%$ for the oil extracted by solvent and $30 \%$ by mechanical pressing $(114.65 \mathrm{mg} / 100 \mathrm{~g}$ and $96.95 \mathrm{mg} / 100 \mathrm{~g}$ respectively).

$\beta$-Sitosterol is a very known anti-oxidant capable to reduce high levels of free radicals by increasing the level of typical anti-oxidant enzymes and reducing damages caused to the DNA (Talcott et al., 2005).

Furthermore, as shown in Table 5 "Citrullus lanatus var. lanatus" oil contains the highest level of $\gamma$-tocopherol (up to $1694.16 \mathrm{mg} / \mathrm{Kg}$ ) as the major component and a total tocopherols content of $2310.3 \mathrm{mg} / \mathrm{Kg}$ followed by "Citrullus lanatus var. citroides" variety which contains up to $1436.84 \mathrm{mg} / \mathrm{Kg}$ of $\gamma$-tocopherol and $4983.65 \mathrm{mg} / \mathrm{Kg}$ of total tocopherols both by cold pressed extraction. 
Table 6. Total polyphenol compounds and antioxidant capacity of oil extracts from "Citrullus lanatus var. lanatus" and "Citrullus lanatus var. citroides" seeds oil extracted by cold press, Soxhlet and SUAE.

\begin{tabular}{llll}
\hline & Oil & $\begin{array}{l}\text { Total phenolic compound content } \\
\text { (mg EGA/100 oil) }\end{array}$ & $\begin{array}{l}\text { Antioxidant activity by the free } \\
\text { radical DPPH \%RSA }\end{array}$ \\
\hline \multirow{3}{*}{ Cold press } & Citrullus lanatus var. lanatus & $34.0 \pm 0.04$ & $51.1 \pm 0.1$ \\
& Citrullus lanatus var. citroides & $77.4 \pm 0.08$ & $65.8 \pm 0.08$ \\
Soxhlet & Citrullus lanatus var. lanatus & $89.5 \pm 0.06$ & $82.4 \pm 0.03$ \\
& Citrullus lanatus var. citroides & $78.8 \pm 0.02$ & $84.8 \pm 0.04$ \\
SUAE & Citrullus lanatus var. lanatus & $71.0 \pm 0.06$ & $55.9 \pm 0.06$ \\
& Citrullus lanatus var. citroides & $63.3 \pm 0.04$ & $54.6 \pm 0.09$ \\
\hline
\end{tabular}

Data shown as means with $\pm \mathrm{SD}$ of three replicates.

Cold press extraction is the most suitable method for extracting most tocopherols, as other methods, such as soxhlet extraction, are subjecting the oil to heat for long periods of time, resulting with a significantly lower tocopherol content.

These high values of $\gamma$-tocopherol grants high anti-oxidant properties for both watermelon's seed oils and an excellent oxidative stability and could signify potential use of the oil for either pharmaceutical and cosmetic purposes (Nyam et al., 2009). Since $\gamma$-tocopherol is the highest tocopherol found, and since it has the most antioxidant power, it can greatly extend the shelf-life of this oil, and protect it from oxidation.

To evaluate the antioxidant capability of vegetable oils, it is possible to proceed by a direct determination with a simple dilution of the oil in an nonpolar solvent such as n-hexane (Bordbar et al., 2013) or intermediate polarity with ethyl acetate (Kalantzakis et al., 2006) another way to determine the antioxidant capacity of the oil is by carrying out an extraction of polar compounds with methanol in such a way that the antioxidants present in the vegetable oil will be present in the polar fraction after separation (Owen et al., 2000) and this is what we did in the present study, the methanol fraction obtained served us as a sample for the determination of the antioxidant capacity and also for the determination of the total phenolic compounds (TPC).

Phenolic compounds are secondary metabolites representing one of the most abundant classes of plant constituents; they are produced in defense against various external factors such as stress, pollutants, infection, etc. And have multiple biological effects (Rao, 2003).

Therefore, we used the colorimetric Folin-Ciocalteu method to determine the total phenolic compounds content (TPC) in the oils methanolic extracts (Tab. 6). The TPC was expressed as gallic acid equivalents (GAE) per $100 \mathrm{~g}$ of oil.

The highest levels of total phenolic compounds were obtained in the oils extracted by Soxhlet, with values of $89.5 \pm 0.06$ and $78.8 \pm 0.02 \mathrm{mg} \mathrm{GAE} / 100 \mathrm{~g}$, for the varieties "Lanatus" and "citroides" and percentages of inhibitions of $82.4 \pm 0.03 \%$ and $84.8 \pm 0.04 \%$ respectively. The cold-pressed oil of the "lanatus" variety was characterized by the lowest total phenol content $(34.0 \pm 0.04 \mathrm{mg}$ GAE/100 g). Our results remain higher than those of Colivet et al. (2016), (53.79, 33.51 and $12.30 \mathrm{mg} \mathrm{GAE} / 100 \mathrm{~g}$ ) (Colivet et al., 2016). Furthermore, the oils tested in this study are still greater than other oils previously reported such as Groundnut oil (3.09 mg GAE/
$100 \mathrm{~g})$, Coconut oil ( $1.8 \mathrm{mg}$ GAE$/ 100 \mathrm{~g})$, Rice bran oil $(0.89 \mathrm{mg}$ GAE$/ 100 \mathrm{~g})$, Mustard oil $(0.56 \mathrm{mg} \mathrm{GAE} / 100 \mathrm{~g})$, Sunflower oil (0.49 mg GAE/100 g) and Sesame oil (0.33 mg GAE/100 g) ((Janu et al., 2014).

\section{Conclusion}

The present study examined the effect of three methods of extraction on the yield and the composition in term of fatty acids, sterols and Tocopherols of two Moroccan watermelon seed oils varieties, "Citrullus lanatus var. lanatus" and "Citrullus lanatus var. citroides".

The watermelon seeds contain high concentrations of linoleic and oleic acids; the two major fatty acids, including high concentrations of phytosterols, in particular $\beta$-sitosterol and high levels of $\gamma$-tocopherols.

By comparing the extraction techniques used, cold-pressed oils exhibited lower extraction yields than solvent extractions, but improved oxidation stability. However, the extraction method did not affect the conservation of functional compounds, comparable profiles of fatty acids, sterols and tocopherols were obtained. On the other hand, total polyphenol compound content and the antioxidant capacity clearly varied from one technique to another and were the higher for the oils extracted by Soxhlet method this time, but all the values obtained contribute to the fact that the oils of "Citrullus lanatus var. lanatus" and "Citrullus lanatus var. citroides" Could be suitable for culinary, pharmaceutical and cosmetic purposes.

\section{References}

Adebisi GA, Olagunju EO. 2011. Nutritional potential of the seed of fluted pumpkin (Telfairia occidentalis). Int J Recent Trends Sci Technol 1: 7-18.

AuthorAID Resource Library. 2019. Available from http://www. agrimaroc.ma/la-culture-de-la-pasteque-marocaine/ (last consult.: 2019/07/17).

Baboli ZM, Kordi AAS. 2010. Characteristics and composition of watermelon seed oil and solvent extraction parameters effects. J Am Oil Chem Soc 87(6): 667-671.

Bimakr M, Abdul Rahman R, Taip FS, Adzahan NM, Sarker MZ, Ganjloo A. 2012. Optimization of ultrasound-assisted extraction of crude oil from winter melon (Benincasa hispida) seed using response surface methodology and evaluation of its antioxidant 
activity, total phenolic content and fatty acid composition. Molecules 17: 11748-11762.

Bordbar S, Ebrahimpour A, Hamid A, Abdul Manap MY, Anwar F, Saari N. 2013. The improvement of the endogenous antioxidant property of stone fish (Actinopyga lecanora) tissue using enzymatic proteolysis. BioMed Res Int 2013: 849-529.

Carr RA. Processing of oil seed crops. In: Robbelon G, Downey RK, Ashiri A, eds. Oil crops of the world. New York: McGraw-Hill, 1989, pp. 226-259.

Cheikhyoussef N, Kandawa-Schulz M, Bock R, de Koning C, Cheikhyoussef A, Hussein AA. 2017. Characterization of Acanthosicyos horridus and Citrullus Lanatus seed oils: two melon seed oils from Namibia used in food and cosmetics applications. Biotech 7: 297.

Colivet J, Oliveira AL, Carvalho RA. 2016. Extraction of oil and phenolic compounds from watermelon (Citrullus lanatus) seeds with supercritical $\mathrm{CO}_{2}$ and pressurized ethanol. Sep Purif Technol 169: 187-195.

Commission regulation EEC/2568/91. 2003. (EEC/2568, 2003).

De conto LC, Gragnani MAL, Ambiel D, Ming CC, Renato G, Lireny AGG. 2011. Characterization of crude watermelon seed oil by two different extractions methods. J Am Oil Chem Soc 88(11): 1709-1714.

El-Adawy TA, Taha KM. 2001. Characteristics and composition of watermelon, pumpkin, and paprika seed oils and flours. Food Chem 74: 47-54.

Huang B, Ke H, He J, et al. 2011. Extracts of Halenia elliptica exhibit antioxidant properties in vitro and in vivo. Food Chem Toxicol 49 (1): $185-190$.

ISO 660. 2009. Corps gras d'origines animale et végétale-Détermination de l'indice d'acide et de l'acidité.

ISO 3657. 2002. Corps gras d'origines animale et végétaleDétermination de l'indice de saponification.

ISO 3960. 2007 Corps gras d'origines animale et végétale-Détermination de l'indice de peroxyde.

ISO 3961. 2009. Corps gras d'origines animale et végétaleDétermination de l'indice d'iode.

ISO 6799. 1991. Détermination de la composition de la fraction de stérol-Méthode par chromatographie en phase gazeuse.

ISO 9936. 2006. Corps gras d'origines animale et végétale «Détermination des teneurs en tocophérols et en tocotriénols par chromatographie en phase liquide à haute performance».

Janu C, Kumar DRS, Reshma MV, Jayamurthy P, Sundaresan A, Nisha P. 2014. Comparative study on the total phenolic content and radical scavenging activity of common edible vegetable oils. $J$ Food Biochem 38: 38-49.

Kalantzakis G, Blekas G, Pegklidou K, Dimitrios B. 2006. Stability and radical-scavenging activity of heated olive oil and other vegetable oils. Eur J Lipid Sci Technol 108(4): 329-335.

Karmel BS, Deman JM, Blackman B. 1982. Nutritional fatty acid and oil characteristics of different agricultural seed. Food Technol 17: 263-267.

Khattab RY, Zeitoun MA. 2013. Quality evaluation of flaxseed oil obtained by different extraction techniques. LWT-Food Sci Technol 53(1): 338-345.

Lister E, Wilsan P. 2001. Measurement of total phenolics and ABTS assay for antioxidant activity (Personal Communication). New Zealand: Crop Research Institute Lincoln.
Lucky OO, John UO, Kate IE, Peter OO, Jude O. 2012. Quantitative determination, metal analysis and antiulcer evaluation of methanol seeds extract of Citrullus lanatus Thunb (Cucurbitaceae) in rats. Asian Pacific J Trop Biomed 2: S804-S808.

Mabaleha MB, Mitei YC, Yeboah SO. 2007. A comparative study of the properties of selected melon seed oils as potential candidates for development into commercial edible vegetable oils. $\mathrm{J} \mathrm{Am} \mathrm{Oil}$ Chem Soc 84: 31-36.

Nolte AJ, von Loesecke HW. 1939. Characteristics and composition of watermelon seed oil (Cuban Queen Variety). J Am Oil Chem Soc 61: 889-891.

Nyam KL, Tan CP, Lai OM, Long K, Man YBC. 2009. Physicochemical properties and bioactive compounds of selected seed oils. LWT-Food Sci Technol 42: 1396-1403.

Olamide A, Olayemi O. 2011. Effects of methanolic extract of Citrullus lanatus seed on experimentally induced prostatic hyperplasia. Eur J Med Plants 1: 171-179.

Owen RW, Mier W, Giacosa A, Hull WE, Spiegelhalder B, Bartsch H. 2000. Phenolic compounds and squalene in olive oils: The concentration and antioxidant potential of total phenols, simple phenols, secoiridoids, lignans and squalene. Food Chem Toxicol 38(8): 647-659.

PORIM Test Methods. 1995. Kuala Lumpur: Palm Oil Research Institute of Malaysia (PORIM).

Rai A, Mohanty B, Bhargava R. 2015. Modeling and response surface analysis of supercritical extraction of watermelon seed oil using carbon dioxide. Sep Purif Technol 141: 354-365.

Rao BN. 2003. Bioactive phytochemicals in Indian foods and their potential in health promotion and disease prevention. Asia Pacific J Clin Nutr 12(1): 9-22.

Ross PJ. 1988. Taguchi techniques for quality engineering. International Editions. New York: McGraw-Hill.

Samaram S, Mirhosseini H, Tan CP, Ghazali HM, Bordbar S, Serjouie A. 2015. Optimisation of ultrasound-assisted extraction of oil from papaya seed by response surface methodology: Oil recovery, radical scavenging antioxidant activity, and oxidation stability. Food Chem 172: 7-17.

Senrayan J, Venkatachalam S. 2018. Optimization of ultrasoundassisted solvent extraction (UASE) based on oil yield, antioxidant activity and evaluation of fatty acid composition and thermal stability of Coriandrum sativum L. seed oil. Food Sci Biotechnol.

Simpson R, Morris GA. 2014. The anti-diabetic potential of polysaccharides extracted from members of the cucurbit family: A review. Bioact Carbohydr Diet Fibre 3: 106-114.

Talcott ST, Duncan CE, Pozo-Insfran DD, Gorbet DW. 2005. Polyphenolic and antioxidant changes during storage of normal, mid, and high oleic acid peanuts. Food Chem 89(1): 77-84.

Van Damme P, Van den Eynden V, Vernemmen P. 1992. Plant uses by the Topnaar of the Kuiseb valley Namib Desert. Afr Focus 8: 223 252.

Varghese S, Narmadha R, Gomathi D, Kalaiselvi M, Devakia K. 2013. Phytochemical screening and HPTLC finger printing analysis of Citrullus lanatus (Thunb.) seed. J Acute Dis 2: 122126.

Vermaak I, Kamatou GPP, Komane-Mofokeng B, Viljoen AM, Beckett K. 2011. African seed oils of commercial importanceCosmetic applications. S Afr J Bot 77: 920-933.

Cite this article as: Ouassor I, Aqil Y, Belmaghraoui W, El Hajjaji S. 2020. Characterization of two Moroccan watermelon seeds oil varieties by three different extraction methods. OCL 27: 13. 